\title{
Concentration of plasminogen and antiplasmin in plasma and serum
}

\author{
SA CEDERHOLM-WILLIAMS
}

From the Department of Haematology, John Radcliffe Hospital, Oxford

SUMMARY The concentrations of plasminogen and fast-acting antiplasmin were measured in 65 normal plasmas and matched sera. Concentrations were decreased in serum by $38 \%$ for plasminogen and $32 \%$ for fast-acting antiplasmin. The decrease in plasminogen level was due to both adsorption of plasminogen to fibrin and reaction with antiplasmin.

Wiman and Collen ${ }^{1}$ proposed a new model for the mechanism of fibrinolysis which in part relies upon the specific association of plasminogen with fibrin. This feature of the model had been proposed some 20 years earlier ${ }^{2}$ but had been criticised by some workers who claimed that plasma and serum plasminogen concentrations were identical and that very little plasminogen could be extracted from ex vivo thrombi. ${ }^{3}{ }^{4}$ Light was shed on this problem when it was shown that plasminogen gains an increased affinity for fibrin following the loss of an N-terminal peptide. $^{5}$ It is now clear that plasminogen and plasmin possess specific fibrin binding sites ${ }^{6}$ which interact with the antifibrinolytic lysine analogues. ${ }^{7}$

The lysine binding sites of plasmin are also important in the reaction between plasmin and the primary plasmin inhibitor, alpha-2-antiplasmin. ${ }^{8}$ This inhibitor exercises a most effective control over plasmin by inactivating the enzyme at such a fast rate that free plasmin has only a very brief existence in plasma. Plasmin inactivation is one of the fastest known protein-protein interactions and the speed of the reaction is determined by the lysine binding sites of plasmin. ${ }^{8}$ Since these sites are occupied when plasmin(ogen) is bound to fibrin the bound enzyme is protected from the antiplasmin. ${ }^{1}$

The plasma and serum concentrations of plasminogen and antiplasmin were re-examined in the light of this new model for fibrinolysis which itself is based upon the properties of the newly discovered alpha-2-antiplasmin. Recently developed techniques for the measurement of plasminogen and antiplasmin were also applied in this study to determine whether sufficient quantities of plasminogen naturally bind to fibrin to induce subsequent clot lysis after the exposure to plasminogen activator.

Accepted for publication 1 April 1981

\section{Material and methods}

Plasma and serum samples were collected from 100 blood donors at a single blood donation session. After the withdrawal of $420 \mathrm{ml}$ blood a further two lots of $9 \mathrm{ml}$ each were collected into tubes containing $1 \mathrm{ml}$ trisodium citrate $(0 \cdot 1 \mathrm{~mol} / \mathrm{l})$ or $\mathrm{NaCl}(0 \cdot 1 \mathrm{~mol} / \mathrm{l})$. All samples were then stored overnight at $4^{\circ} \mathrm{C}$ for $15 \mathrm{~h}$, after which time they were centrifuged at $4000 \mathrm{~g}$ for $30 \mathrm{~min}$ and $2 \mathrm{ml}$ of the top layer of plasma or serum removed. This aliquot was divided into two equal portions, one lot pooled and both lots stored at $-30^{\circ} \mathrm{C}$ until assayed. If a blood sample did not correspond exactly to the $1 \mathrm{ml}$ calibrated mark on the tube, then both plasma and serum samples were discarded. Thirty-six such samples were discarded.

Plasminogen assay was carried out by a Gilford enzyme rate analyser (Gilford Inc., Ohio) with the method described by Friburger and Knos. ${ }^{9}$ Streptokinase and the chromogenic substrate D-valyl-Dleucyl-L-lysy-p-nitroanalide were both purchased from KabiVitrum, London. Total antigenic levels of plasminogen were also measured using radial immunodiffusion plates (Hoechst Pharmaceuticals Ltd, Hounslow). Results were expressed as percentages of pooled normal plasma.

Fast acting antiplasmin was assayed using the Coatest antiplasmin assay kit (KabiVitrum Ltd, London) adapted directly for use on the Gilford enzyme rate analyser. This assay gives results which are directly proportional to the levels of alpha-2-antiplasmin concentrations. ${ }^{10}$ Results were expressed as percentages of pooled normal plasma.

Fibrinogen concentrations ${ }^{11}$ were measured by reference to a standard curve constructed from a reference 
plasma of known fibrinogen concentration (Plasma Control 'Plus', Boehringer Mannheim GmbH, FDR).

Other reagents used were 6-aminohexanoic acid (Koch Light Ltd, Colnbrook) and bovine thrombin (Diagen Diagnostics, Thame).

\section{Results}

The concentration of plasminogen and antiplasmin in normal plasma and serum samples is shown in Table 1. When compared to plasma levels the plasminogen concentration was reduced by some $38 \%$ in serum and antiplasmin by some $32 \%$. Antigenically detected plasminogen was reduced by only $16 \%$ in serum. The plasma fibrinogen concentrations were $206 \pm 59.3 \mathrm{mg} / \mathrm{dl}(6.08 \mu \mathrm{mol} / \mathrm{l})$.

To determine the quantity of plasminogen bound to fibrin via the lysine sensitive fibrin binding site the following experiment was performed. Pooled plasma (65 samples) was mixed with 6-aminohexanoic acid to a final concentration of $180 \mathrm{mmol} / 1$ and clotted with one unit of thrombin per $\mathrm{ml}$ of plasma and incubated at room temperature for $60 \mathrm{~min}$. Plasminogen assays were performed on the plasma and serum and upon pooled serum to which 6-aminohexanoic acid $(180 \mathrm{mmol} / \mathrm{l})$ had been added (Table 2). Functional plasminogen was reduced by $26 \%$ in the freshly prepared serum.

\section{Discussion}

When blood was allowed to clot for $15 \mathrm{~h}$ at $4^{\circ} \mathrm{C}$ the concentrations of functional plasminogen and antiplasmin are reduced in serum by some $38 \%(0.61$ $\mu \mathrm{mol} / \mathrm{l})$ and $32 \%(0.32 \mu \mathrm{mol} / \mathrm{l})$ respectively. The antigenically determined plasminogen on the other hand was only reduced by $16 \%(0 \cdot 26 \mu \mathrm{mol} / \mathrm{l})$. This discrepancy between functional and antigenic concentrations of plasminogen is possibly due to the radial immunodiffusion technique detecting both free plasminogen and plasmin-antiplasmin complexes.

Since the reaction between plasmin and alpha-2antiplasmin occurs on a $1: 1$ basis a reduction in the normal $1 \mu \mathrm{mol} / 1^{12}$ concentration of antiplasmin by $32 \%(0.32 \mu \mathrm{mol} / \mathrm{l})$ represents a similar reduction in plasminogen of $0.32 \mu \mathrm{mol} / \mathrm{l}$. Thus the reduction of serum plasminogen appears to be due to two processes; $20 \%(0.32 \mu \mathrm{mol} / \mathrm{l})$ by reaction with antiplasmin and the remaining $18 \%(0.29 \mu \mathrm{mol} / \mathrm{l})$ by fibrin binding. This view is supported by the discrepancy in the antigenically determined plasminogen concentration which is reduced by only $16 \%(0 \cdot 26$ $\mu \mathrm{mol} / \mathrm{l})$ and by the finding that when serum is produced from pooled plasma in the presence of 6-aminohexanoic acid (which prevents the binding of plasminogen to fibrin) the reduction in serum plasminogen is $26 \%(0.42 \mu \mathrm{mol} / \mathrm{l})$. This difference suggests that some $14 \%(0 \cdot 22 \mu \mathrm{mol} / \mathrm{l})$ of plasminogen has been removed on the fibrin clot.

The activation and subsequent inhibition of $20 \%$ $(0.32 \mu \mathrm{mol} / \mathrm{l})$ of the plasminogen probably occurred during the $15 \mathrm{~h}$ incubation period in the presence of the blood cells. Evidently a small proportion (14$18 \%$ ) of plasminogen binds to fibrin during the clotting of normal blood but whether this quantity (molar ratio of plasminogen:fibrin is $1: 20$ ) is sufficient to cause complete fibrinolysis in the presence of plasminogen activators and antiplasmins remains to be determined.

Thanks are due to the staff of the Regional Transfusion Centre at this hospital for the collection of

Table 1 Concentrations of plasminogen and antiplasmin in plasma and serum of 65 paired samples. The micromolar concentrations (in parentheses) are obtained from a plasminogen concentration of $14.6 \mathrm{mg} /$ dl determined by radial immunodiffusion and from the reported ${ }^{12}$ micromolar concentration for alpha-2-antiplasmin

\begin{tabular}{|c|c|c|c|}
\hline & $\begin{array}{l}\text { Plasma concentration } \\
(\% \text { and } \mu \mathrm{mol} / \mathrm{l})\end{array}$ & $\begin{array}{l}\text { Serum concentration } \\
(\% \text { and } \mu \mathrm{mol} / \mathrm{l})\end{array}$ & $\begin{array}{l}\text { Difference } \\
(\% \text { and } \mu \mathrm{mol} / l)\end{array}$ \\
\hline $\begin{array}{l}\text { Plasminogen } \\
\text { (functional) }\end{array}$ & $99 \cdot 0 \pm 13 \cdot 8(1 \cdot 6)$ & $62.8 \pm 9.9(0.99)$ & $37.9 \pm 10.4(0.61)$ \\
\hline $\begin{array}{l}\text { Plasminogen } \\
\text { (antigenic) }\end{array}$ & $104 \cdot 6 \pm 23 \quad(1 \cdot 67)$ & $89.0 \pm 13.9(1.41)$ & $15 \cdot 6 \pm 4 \cdot 1(0 \cdot 26)$ \\
\hline $\begin{array}{l}\text { Antiplasmin } \\
\text { (functional) }\end{array}$ & $99.8 \pm 10.9(1.0)$ & $69.4 \pm 9.9(0.68)$ & $32 \cdot 3 \pm 11 \cdot 0(0 \cdot 32)$ \\
\hline
\end{tabular}

Table 2 Difference in plasminogen concentrations when pooled plasma $(n=65)$ was clotted in the presence and absence of $180 \mathrm{mmol} / \mathrm{l}$ 6-aminohexanoic acid (6-AHA). Each value is the mean of four determinations

\begin{tabular}{|c|c|c|c|}
\hline & $\begin{array}{l}\text { Pooled plasma with } \\
\text { added } 6-A H A\end{array}$ & $\begin{array}{l}\text { Pooled serum with } \\
\text { added } 6-A H A\end{array}$ & $\begin{array}{l}\text { Pooled serum } \\
\text { prepared with 6-AHA }\end{array}$ \\
\hline $\begin{array}{l}\text { Plasminogen concentration } \\
\text { (as \% of plasma) }\end{array}$ & 100 & 60 & 74 \\
\hline
\end{tabular}


the blood samples and to Mr N Jones, KabiVitrum, for the gift of the antiplasmin assay kits used in this study.

\section{References}

${ }^{1}$ Wiman B, Collen D. Molecular mechanism of physiological fibrinolysis. Nature $1978 ; 272: 549-50$.

${ }^{2}$ Alkjaersig N, Fletcher AP, Sherry S. The mechanism of clot dissolution by plasmin. J Clin Invest 1959;38: 1086-95.

${ }^{3}$ Hedner U, Nilsson IM, Robertson B. Determination of plasminogen in clots and thrombi. Thrombosis et Diathesis Haemorrhagica 1966;15:38-50.

${ }^{4}$ Ogston D, Ogston CM, Fullerton HV. The plasminogen content of thrombi. Thrombosis et Diathesis Haemorrhagica $1966 ; 15: 220-30$.

${ }^{5}$ Thorsen $\mathrm{S}$. The differences in the binding of native plasminogen and plasminogen modified by proteolytic degradation: influence of omega-amino acids. Biochim Biophys Acta 1979;579:142-54.

- Wiman B, Wallen P. The specific interaction between plasminogen and fibrin. A role for the lysine binding site. Thromb Res 1977 ; 1 :213-22.
${ }^{7}$ Cederholm-Williams SA, Swain A. The effects of fibrinogen degradation products and some lysine analogues on the dissociation of plasmin(ogen)-fibrin complexes. Thromb Res 1979;16:705-13.

${ }^{8}$ Wiman B, Collen D. On the kinetics of the reaction between human antiplasmin and plasmin. Eur J Biochem $1978 ; 84: 573-8$.

' Friburger P, Knos M. Plasminogen determination in human plasma. In: Scully MF, Kakkar VV, eds. Chromogenic peptide substrates; chemistry and clinical usage. Churchill Livingstone, 1979.

10 Teger-Nilsson AC, Friburger P, Gyzander E. Determination of a new rapid plasmin inhibitor in human blood by means of a specific tripeptide substrate. Scand J Clin Invest 1977;37:403-9.

11 Vermylen C, de Vreker A, Verstraete M. A rapid method for assay of fibrinogen fibrin polymerisation time (FPT Test). Clin Chim Acta 1963;8:418-24.

12 Collen D, Wiman B. Fast-acting antiplasmin inhibitor in human plasma. Blood $1978 ; 51$ :563-9.

Requests for reprints to: Dr SA Cederholm-Williams, Department of Haematology, John Radcliffe Hospital, Oxford OX3 9DU, England. 